\title{
Geochemical Evaluation for the Hydrocarbon Potential of Source Rocks in the Anza Basin
}

\author{
Bett Gilbert1', Daniel Olago' ${ }^{1}$, Daniel Ichangi ${ }^{1}$, Bernard Rop ${ }^{2}$ \\ ${ }^{1}$ Department of Geology, University of Nairobi, Nairobi, Kenya \\ ${ }^{2}$ Department of Mining, Materials and Petroleum Engineering, Jomo Kenyatta University of Agriculture and Technology, \\ Nairobi, Kenya \\ Email: gbett@jkuat.ac.ke
}

How to cite this paper: Gilbert, B., Olago, D., Ichangi, D. and Rop, B. (2021) Geochemical Evaluation for the Hydrocarbon Potential of Source Rocks in the Anza Basin. International Journal of Geosciences, 12, 572-583.

https://doi.org/10.4236/ijg.2021.126032

Received: May 29, 2021

Accepted: June 26, 2021

Published: June 29, 2021

Copyright () 2021 by author(s) and Scientific Research Publishing Inc. This work is licensed under the Creative Commons Attribution International License (CC BY 4.0).

http://creativecommons.org/licenses/by/4.0/

\section{Open Access}

\begin{abstract}
Anza basin is located in the extensional arm of the central African rift system in the North-Eastern part of Kenya. Cretaceous sedimentary rocks were sampled from the four wells namely, Chalbi-3, Sirius-1, Ndovu-1 and Kaisut-1. Anza basin occurs on a fault block within a Paleocene-Cretaceous rift basin. The methodological approach used for the evaluation of source rocks included petrophysical and geochemical methods to ascertain their potential. Well sections with a higher shale-volume ratio were sampled for geochemical screening to determine the organic richness and thermal maturity of potential source rocks, respectively. Source rock with organic richness $\geq 0.5 \%$ were evaluated further for their petroleum potential using Rock-Eval pyrolysis to determine their thermal maturity, organo-facies and in-situ generated hydrocarbons present in sedimentary facies. The geochemical evaluation of rock samples from the drilled wells' sections of Chalbi-3 and Sirius-1 confirmed both oil and gas potential. Gas Chromatography and Mass Spectrometry (GCMS) were used to characterize the biomarker signatures and oil-oil correlation of Sirius-1 samples. A predictive model was developed to integrate the petrophysical and geochemical data to reveal hydrocarbons' potential in the Anza basin.
\end{abstract}

\section{Keywords}

Geochemical Evaluation, Kerogen, Maturity, Petroleum Potential, Predictive Model

\section{Introduction}

Anza basin is a sedimentary basin located in the northeastern part of Kenya (Figure 1(a)). Anza basin has been referred to as the termination of the Central 
African Rift System in Chalbi sub-basin and an extension of the Melut and Muglad rift basins in South Sudan (Figure 2) where working petroleum systems [1] exist. Anza basin evolved through extension tectonics that brought out continental rifting during the Gondwanaland break-up in the Late Paleozoic time and continued in the Mesozoic and Tertiary [2] [3] [4]. The stratigraphic layout of the Anza basin included Precambrian basement rocks overlain by Upper Jurassic-Cretaceous clastic [4] rock with minor outcrops of limestone within the Anza rift system. However, due to post-rifting occurrences, volcanic and sedimentary units [3] were deposited including sandstone, mudstone and siltstone. Anza basin has dominantly continental, fluvial and lacustrine [2] [3] [4] sediment provenance with sandstone beds. Marine facies occasionally occurred in some sections which explain the paleoenvironmental conditions in the region. This research aimed to determine the hydrocarbon potential of the Anza basin using data from four drilled wells (Figure 1(b)) namely: Chalbi-3, Sirius-1, Ndovu-1 and Kaisut-1. The target depth interval has Cretaceous-Tertiary rocks which were assessed using petrophysical and geochemical analysis of source rocks. Geochemical study is imperative science for unravelling the properties of source rock [5] and reduces the uncertainty inherent in petroleum exploration regarding project viability [6]. Therefore, it revolved around resource origin and producibility [7] [8] that included describing organic facies associated with paleo-parameters [9], burial history and post-depositional geologic processes that occurred in the basin.
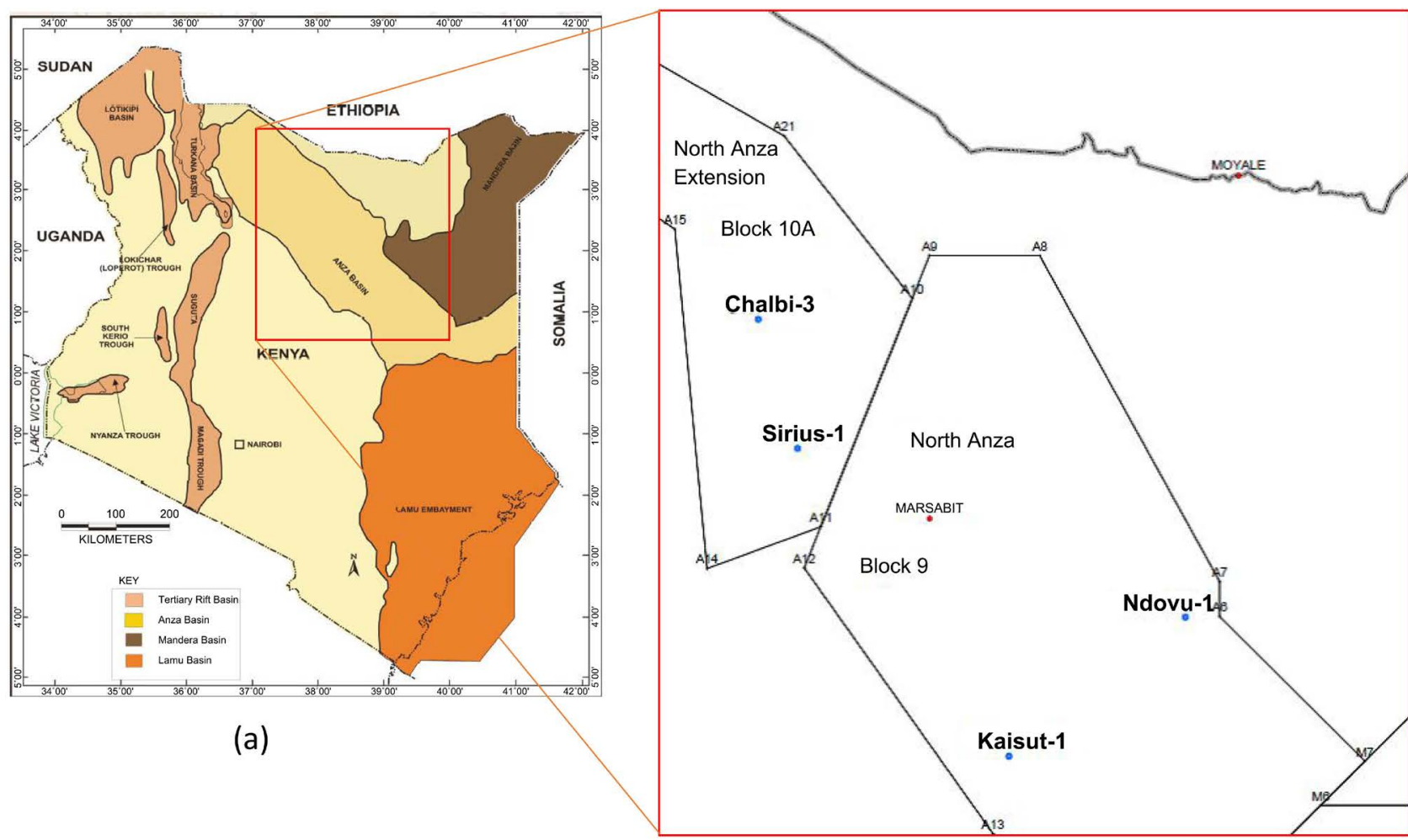

(b)

Figure 1. Location map for the study area. Source: National Oil Corporation of Kenya. 


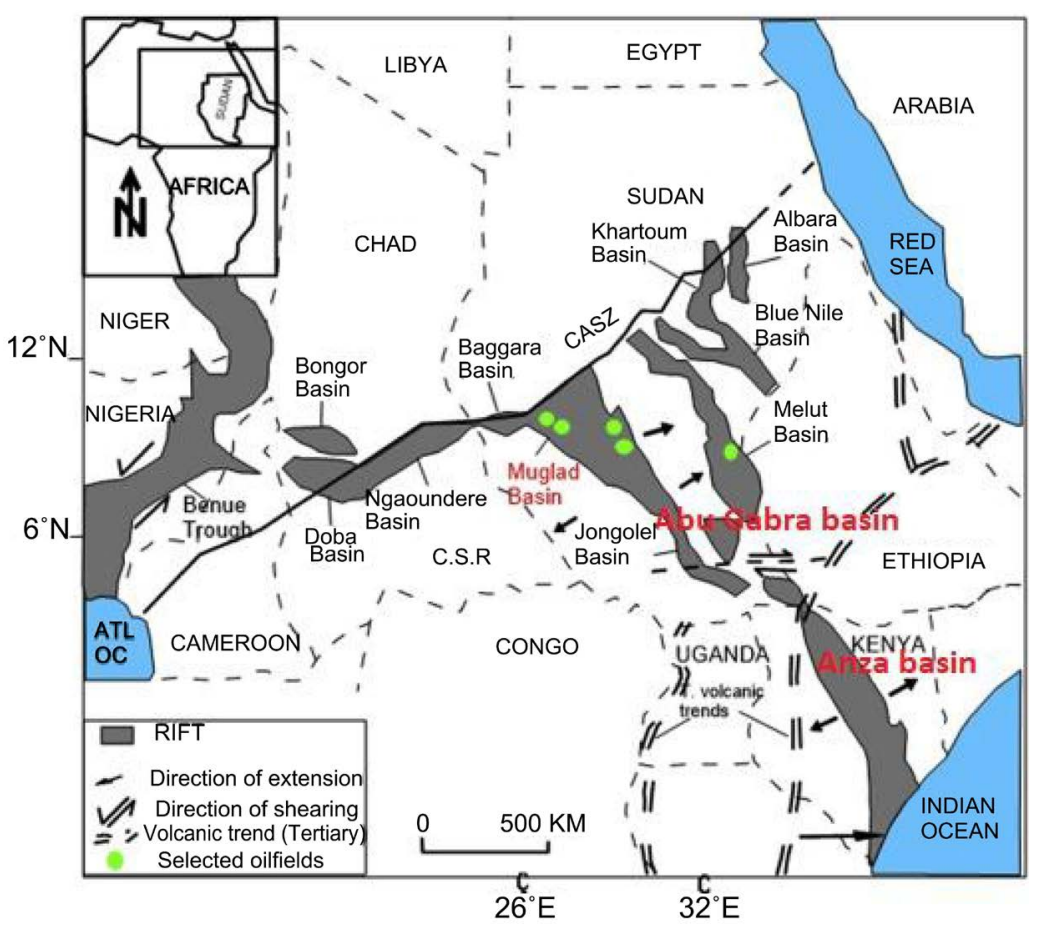

Figure 2. Abu Gabra basin (an extension of the Muglad basin) in South Sudan (Modified from [1]).

Anza region is generally a product of post-rifting [10] depositional sequences that occurred in the Kaisut and Ndovu sag sub-basins. To assess the source rocks parameters, geochemical analyses were applied to determine total organic carbon (TOC), generating source potential (S2), Production Index (PI), Oxygen Index (OI), Hydrogen Index (HI) and $\mathrm{T}_{\max }$ [9]. According to Rop [2], the Cretaceous sedimentary sequences of the Anza Basin, those of the Abu Gabra (Figure 2) (South Sudan) and Sharaf Formations (Sudan) share a common tectonic setting and lithological composition which triggered this study to assess their potential.

\section{Methods}

Petrophysical study involved evaluation of subsurface rock physical features in order to portray source rock properties associated with petroleum accumulation that included porosity, fluid inclusions, resistivity and shalyness. Gamma-ray log illustrated shale volume ratios [11], neutron-density log [12] [13] gave rock data for porosity calculation and the deep resistivity log was then used to compute for water saturation [14] [15]. The objective of formation evaluation was to quantitatively locate and determine the shale volume, effective porosity and water saturation of the source rocks using Technlog software. The depth intervals with high shale content were sampled for geochemical analysis.

Total Organic Carbon (TOC) analysis investigated the organic richness and spatial distribution [8] of organic components in the samples, which is an initial step for evaluating petroleum characterization [6] [16]. $1 \mathrm{mg}$ sample was pulve- 
rized and treated with hot $10 \% \mathrm{HCl}$ to remove carbonate [17] contaminants. Then heated at $1200^{\circ} \mathrm{C}$ in an inducing furnace. TOC is expressed as a percentage of the dry weight of the organic content in the sample, denoted as wt\% TOC [18] [19]. Rock-Eval Pyrolysis was subsequently undertaken for over 0.5\% TOC [20] to assess their kerogen type and thermal maturity. The pyrolysis process is the programmed heating [21] of source rock in order to break its complex composition [22] to mimic subsurface natural phenomena. The resultant parameters were expressed in $\mathrm{mg} / \mathrm{g}$ of rock as $\mathrm{S} 1, \mathrm{~S} 2, \mathrm{~S} 3$ and $\mathrm{T}_{\max }$. Gas Chromatography-Mass Spectrometry (GC-MS) was used to investigate mass spectra and mass to charge $(\mathrm{m} / \mathrm{z})$ ratios for associated compounds in order to characterize the biomarker compositions.

\section{Results}

\subsection{Total Organic Carbon}

Kaisut-1 well samples have siliciclastic sediments with poor shale content. It had the lowest margin of organogenic sedimentary rocks below $0.5 \%$ TOC threshold [8] [9] [23]. Ndovu-1 well has carbonate sediments from $2664-3141 \mathrm{~m}$ and minor shale ratios from $3180 \mathrm{~m}$ downwards from Paleocene age. Chalbi-3 had sandstone with different shale proportion that released better TOC values (Figure 3) in which two $(1713 \mathrm{~m}, 2680 \mathrm{~m}$ ) samples progressed for pyrolysis. Sirius-1 well demonstrated the very good wt $\%$ TOC at 1495 - $1510 \mathrm{~m}$ depth.

\subsection{Rock-Eval Pyrolysis}

Chalbi-3 samples had $0.39 \%$ - 0.63\% TOC content. The HI values (Figure 4(a)),

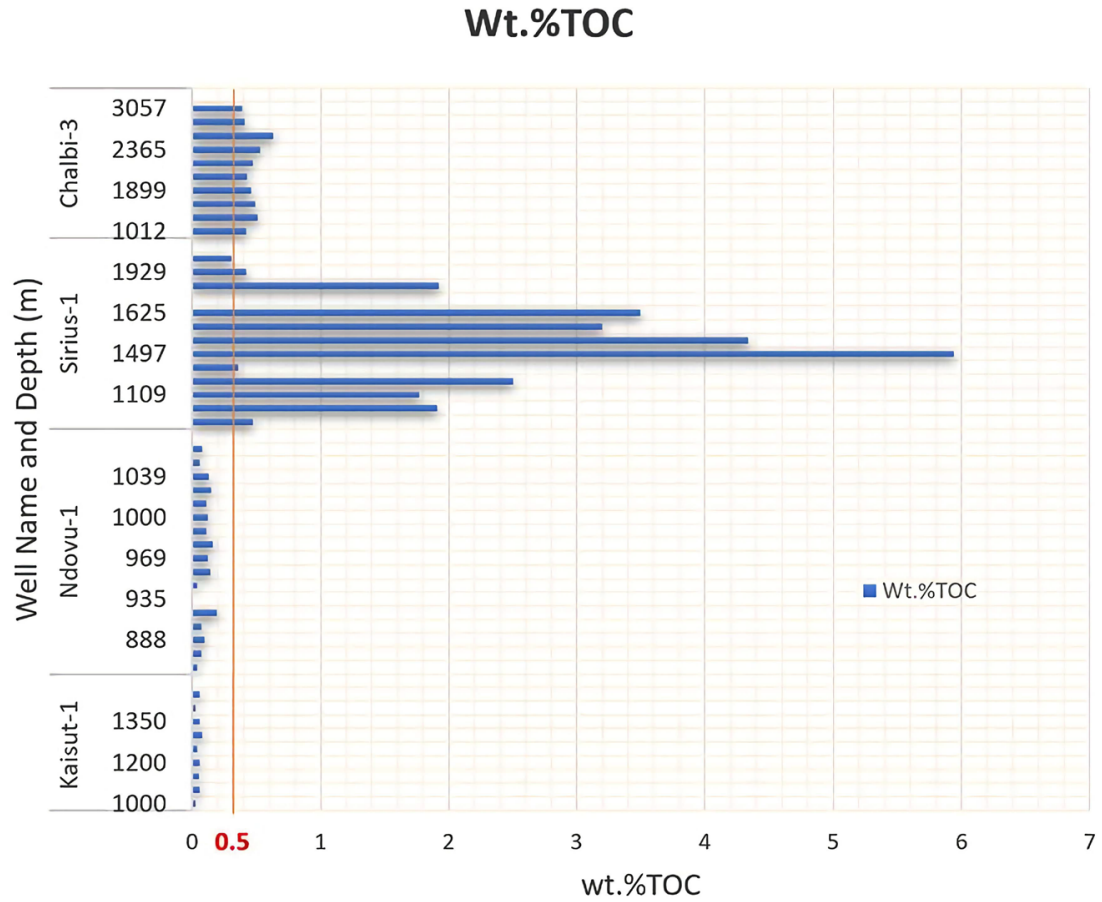

Figure 3. Wt\% TOC results. 


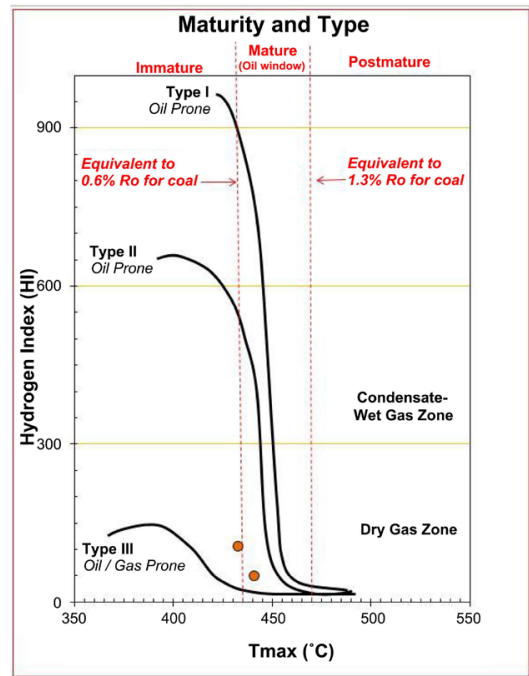

(a)

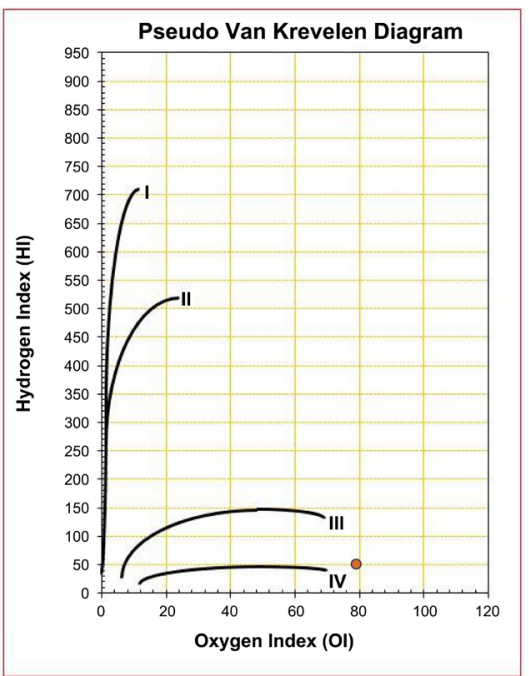

(b)

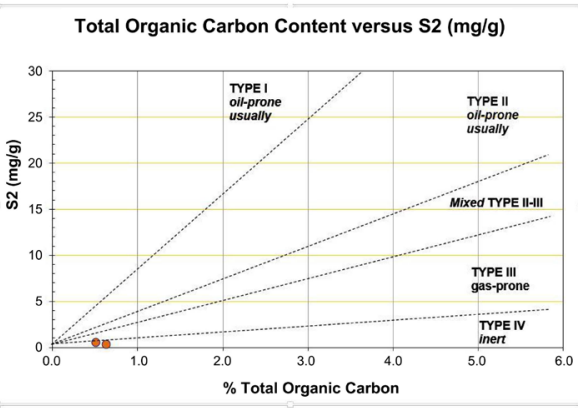

(c)

Figure 4. Chalbi-3 pyrolysis results.

Figure 4(b)) illustrated that both samples occur within the gas window [24]. Further analyses show samples were kerogen types III and IV [9], respectively. The sampled depths $(1713 \mathrm{~m}$ and $2680 \mathrm{~m}$ ) had fair-good and mature source rocks [23] [25] [26] but with minimal ratios of kerogen type III. (Figure 4(c)) ranked both samples as poor and non-producible [24] [27] [28].

Sirius-1 well had high TOC in the range of $1.77 \%-5.945 \%$ displayed from 1106 - $1725 \mathrm{~m}$ depth section, thus very good source rocks [21] [22]. Pyrolysis data portrayed that free HCs (S1) are in the order of 0.16 and $0.98 \mathrm{mg} \mathrm{HC} / \mathrm{g}$ while thermally extractable HCs (S2) span from $2.96-60.01 \mathrm{mg} \mathrm{HC/g}$ [17]. The samples show $\mathrm{T}_{\max }$ peak values in the range of $441^{\circ} \mathrm{C}-444^{\circ} \mathrm{C}$ depicting thermally mature [21] OM.

HI range between 155 and $1010 \mathrm{mg} \mathrm{HC/g}$ TOC (Figure 5(a)) reflect oil-bearing zone enriched with OM [29]. HI extend from 765 - $1010 \mathrm{mg} \mathrm{HC/g}$ TOC in the depth section from 1497 - $1521 \mathrm{~m}$ suggested organic-rich oil-prone type 1 [26] [30] [31] while the rest of the samples are of oil-prone Type II (Figure 5(b)). The low PI indices $(0.01-0.05)$ indicated the origin of extractable OM (S1) to be inherent source rocks and have not migrated [24] from other places. S2 versus TOC (Figure 5(c)) illustrated various kerogen types from type I-III of the source rocks. All the samples except $1520 \mathrm{~m}$ depth had mature Cretaceous shale deposits. Accordingly, Kerogen type I - II (oil) and, type II - III (oil-gas condensate) and III (early gas) [21] [22] occurred.

\subsection{Gas Chromatography-Mass Spectrometry}

Sirius-1 samples were evaluated for saturated fractions of the rock extract for $\mathrm{n}$-alkanes, steranes, diasterane and hopane distributions. Saturated hydrocarbons displayed unimodal distributions in the range n-C27-n-C30 suggesting derivation from terrestrial OM [32] [33] due to the abundance of heavy carbon 


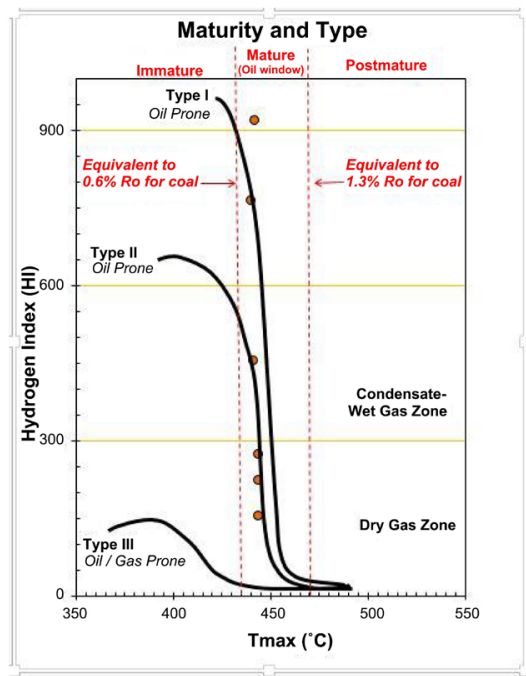

(a)

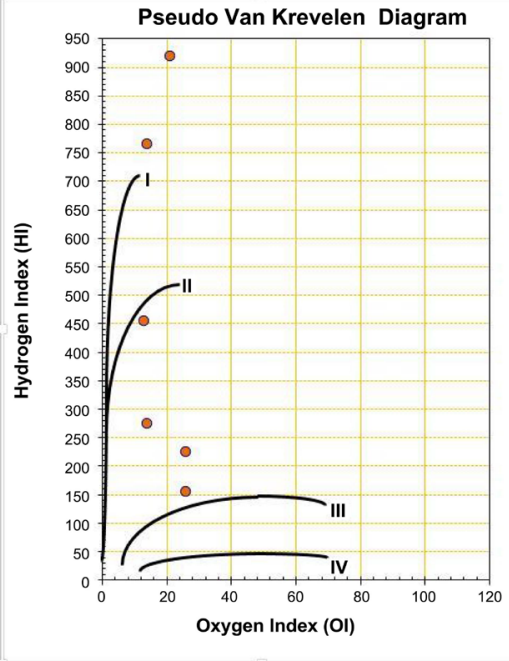

(b)

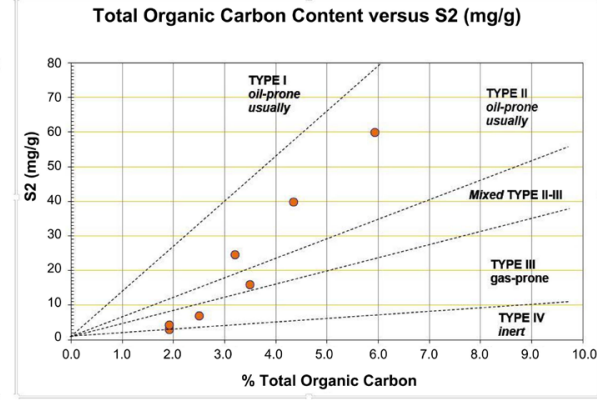

(c)

Figure 5. Sirius-1 pyrolysis results.

numbers. In the samples, isoprenoids; pristine and phytane are present in low concentrations but higher than the respective $\mathrm{nC17}$ and $\mathrm{nC18}$. The higher $\mathrm{ab}$ undance of isoprenoids relative to $\mathrm{nC} 17$ and $\mathrm{nC} 18$ would be suggestive of low maturity [6] [34]. The samples had low volume indices of tricyclic terpanes compared to the hopanes that symbolized thermal maturity [34] [35]. Hopanes extend to $\mathrm{C}_{35}$ hopanes and dominated by $\mathrm{C}_{30} \alpha \beta$ hopanes and $\mathrm{C}_{29}$ norhopane, $17 \alpha$ (H)-trisnorhopane (Tm), with the former being the most dominant.

The high abundance of $\mathrm{C}_{30} \alpha \beta$ hopanes relative to $\mathrm{C}_{29}$ norhopane, $17 \alpha(\mathrm{H})$ trisnorhopane $(\mathrm{Tm})$ suggests derivation from clastic source rocks. Isomerisation ratios of the $\mathrm{C}_{31}$ and $\mathrm{C}_{32} \alpha \beta$-hopanes [36] flanged from 0.50 - 0.56 indicating that they were mature. This corresponded to $\mathrm{T}_{\max }$ and other maturity biomarkers such as the low $\mathrm{C}_{30}$ moretane/hopane ratios.

All samples contain $\mathrm{C}_{21}$ to $\mathrm{C}_{29}$ steranes. However, few in elemental numbers relative to pentacyclic terpanes as shown by the low sterane/hopane ratio (Figures 6(a)-(d)) suggesting contributions from prokaryotic organisms (bacteria) to the OM [37] [38].

The samples display high $\mathrm{C}_{28} / \mathrm{C}_{29}$ sterane ratio (Figures $7(\mathrm{a})-(\mathrm{d})$ ) in the range 0.4 - 1.25 indicating moderate heterogeneity of phytoplankton assemblages [39] in the OM. The extracts generally show dominance of $\mathrm{C}_{28}$ and $\mathrm{C}_{27}$ relative to $\mathrm{C}_{29}$ steranes implying algal OM type [35] [36]. This agreed with results from pyrolysis that showed type I/II OM. $\mathrm{C}_{29}$ regular sterane ratios range between $0.56-0.63$ characterizing oil expulsion stage [19] [39]. These tallies with results from $\mathrm{T}_{\max }$ and hopane isomerisation ratios that showed type I/II OM.

\subsection{Correlation Model}

A correlation model was constructed to map the well sections with Sirius-1 petrophysical and geochemical results (Figure 8). At Sirius-1 well section between 


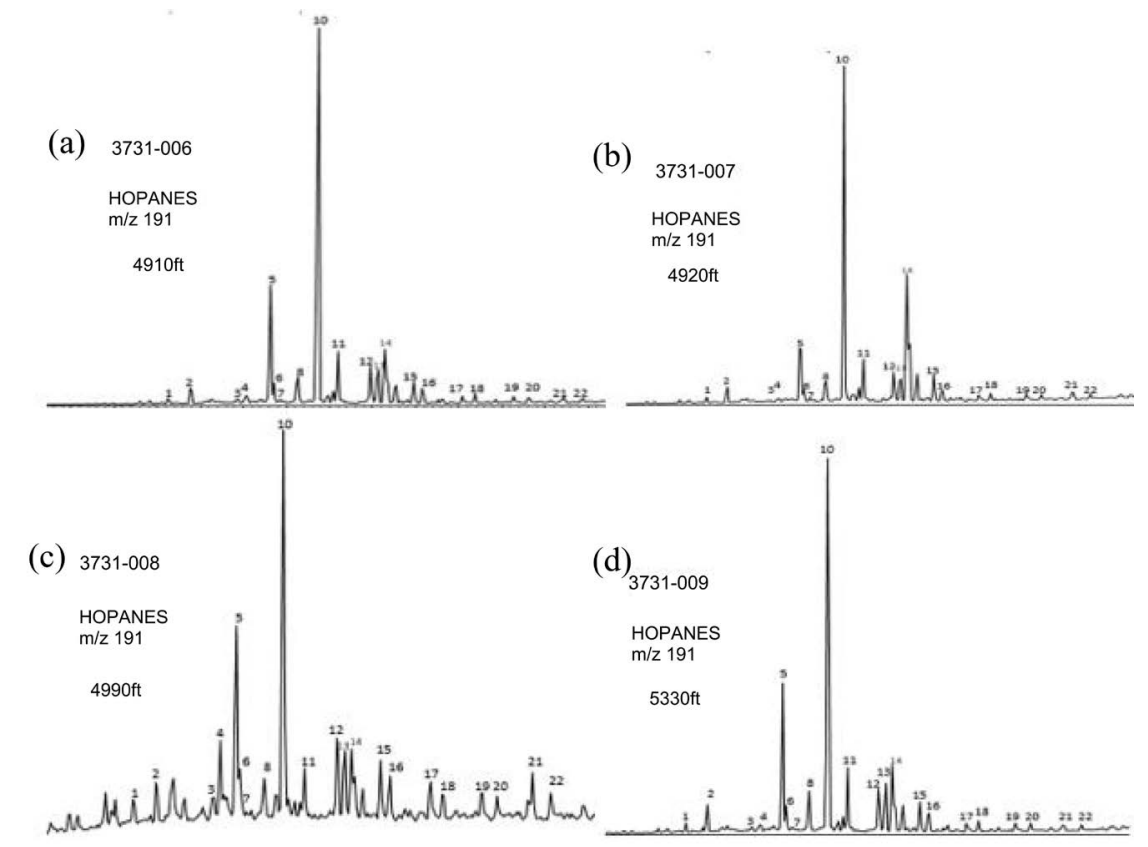

Figure 6. m/z 191 displayed the distribution of the hopane part of pentacyclic terpanes.

(a)

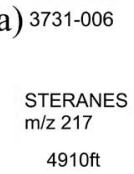

$3731-007$
STERANES
$m / z 217$

$4920 \mathrm{ft}$

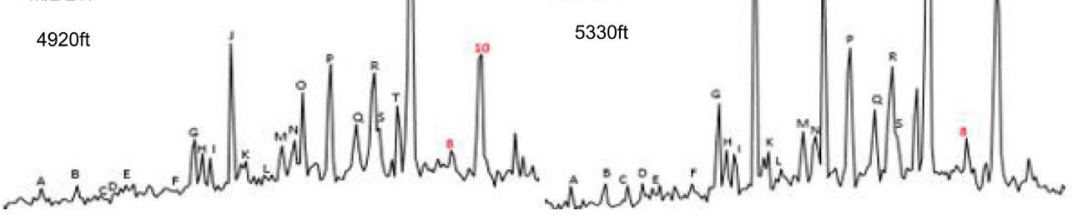

Figure 7. m/z 217 fragmentogram for Sirius-1 extract showing sterane biomarker distribution.

$1495-1625 \mathrm{~m}$, had very good (3.2 - $5.94 \mathrm{wt} \%$ TOC) and mature source rocks capable to generate gas-oil condensate to oil-based on their relationship with HI. Sirius-1 well evidently is potential for hydrocarbon based on the analysed sampled depth sections. Petrophysical studied well depths from 2540 - $2597 \mathrm{~m}$ (for which samples were not available) highlighted deeper depths with high shale content which should be considered for further assessment. 


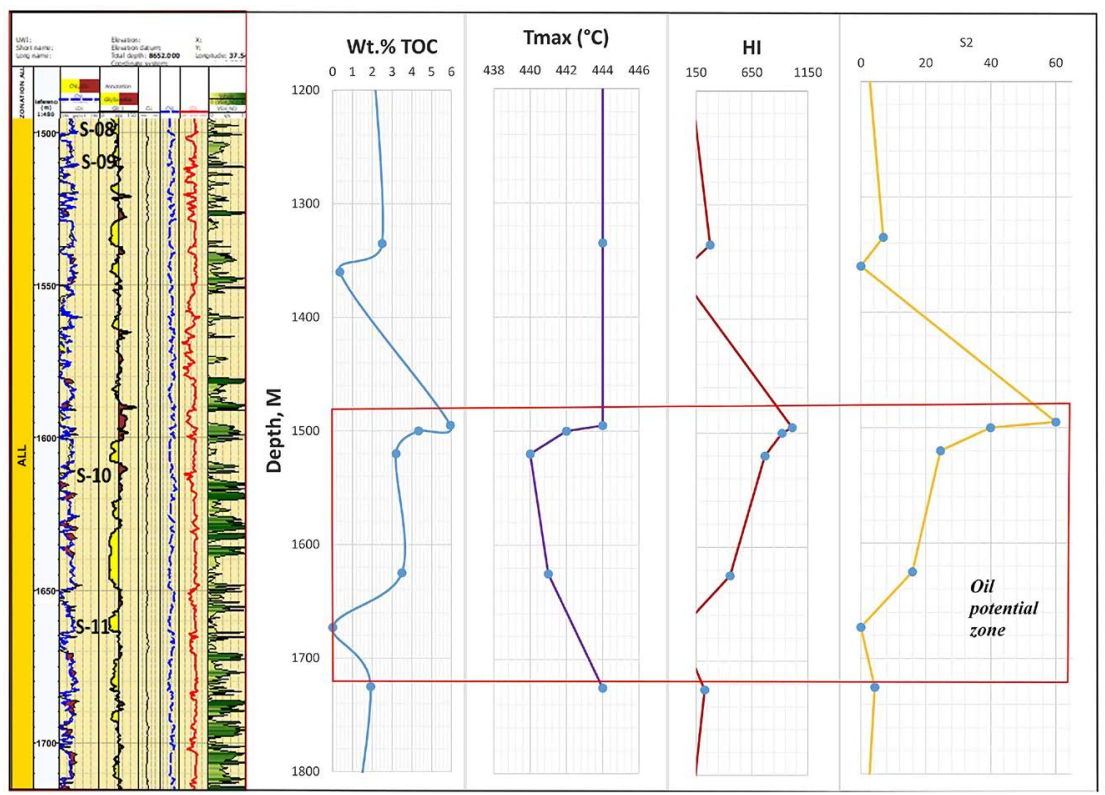

Figure 8. Correlation of petrophysical and geochemical study (red box) of Sirius-1 well.

\section{Discussion}

Organic richness and maturity of source rocks have increasingly been used to ascertain the occurrence of $\mathrm{HC}$ during the exploration stage. In this study, source rocks were visually examined for shale content and sampled for geochemical analysis. The geochemical signatures associated with source rock types provided information about the depositional environment and their organic origin, burial history and maturity. The four wells namely Kaisut-1, Ndovu-1, Chalbi-3 and Sirius-1 were case studied to assess the HC parameters occurring in the Anza Basin.

Kaisut-1 well was primarily a shallow well with a total depth of $1450 \mathrm{~m}$. It encountered quartz sandstones with minimal shale content of Tertiary origin that resulted in very poor source rocks. Ndovu-1 well samples were from the Paleocene-Cretaceous age with sandstone-mudstone bearing shale deposited sediments. However, evaluation provided very poor ratios of wt $\%$ TOC. For probable depths, well sections for up to Mesozoic should be analyzed.

Chalbi-3 had a confirmable volume of kerogen type III and mature source rocks but with very low HI compared to OI. Both samples were gas prone but had little extractable ratios of HC. Sirius-1 well has deep well intervals with good shale volume, high wt $\%$ TOC, and producible mature oil content. Sirius- 1 well was the most productive as per both the petrophysical characterization and geochemical evaluation of the Cretaceous shaly rocks. Therefore, the correlation model portrayed good source rock depositions and enrichment of mature extractable HC content.

\section{Conclusions}

This study was geared towards unravelling the hydrocarbon potentiality of Anza 
basins. Anza basin has deep sediment deposition sequences (2000 - 11,000 m) which deepen towards the South Anza sub-basin. It shares similar tectonic and lithological compositions with South Sudan's Muglad basin which is oil-producing. Petrophysical and geochemical methods were used to assess the origin, occurrence and accumulation in the basin.

Kaisut-1 was drilled to a total depth of $1450 \mathrm{~m}$ on an anticlinal structure dominated by Cretaceous sandstone sediments with thin alternatives of shale and clay content. The sampled depth had sand grains with small shale content. Therefore, negligible organic content was recovered which originated from reduction environments that affected the preservation of OM. Ndovu-1 well was drilled to explore the Paleocene and Mesozoic sediments. Sampled depths portrayed little intervals of shale and poor source rocks as per TOC content. Both Kaisut-1 and Ndovu-1 were drilled in the South-Anza sub-basin. Unlike Kaisut-1, Ndovu-1 well had higher shale content but below $0.5 \%$ TOC threshold.

Sirius- 1 and Chalbi-3 wells were drilled in the North Anza sub-basin to assess the Cretaceous sediments. Chalbi-3 well encountered predominantly PaleoceneCretaceous sandstones interbedded with thin intervals of siltstone, claystone and shale. Cretaceous source rocks with high shale content occurred at several depth intervals from $1500 \mathrm{~m}$ to $2390 \mathrm{~m}$ at Sirius-1 well. Petrophysical layout of Sirius-1 well profile revealed varied but increasing volumes of shale content which suggested potential source rock sections occurred. Sirius- 1 well has potentially extractable oil at depth intervals from $2540-2597 \mathrm{~m}$. The sections act as reservoir depth with over $30 \%$ porosity that allowed for the accumulation of HC. The accumulation of good source rocks within the sampled depths indicates the presence of an active petroleum system. However, storage and handling of the drill or core cuttings required good storage conditions in order to preserve samples for future assessment.

Anza basin stratigraphic layout trend southwards in sediment deposition which implies a deeper burial history sequence for potential source rocks. Petrophysical study for Sirius-1 well revealed higher shale ratio content extending to deeper depths which could be further studied to map the source rock enrichment. In addition, future study is encouraged to explore suitable trapping mechanisms that were present and/or absent at the time of petroleum generation, migration, accumulation, and preservation.

\section{Conflicts of Interest}

The authors declare no conflicts of interest regarding the publication of this paper.

\section{References}

[1] Mohamed, A. (2002) Petroleum Maturation Modelling, Abu Gabra-Sharaf Area, Muglad Basin, Sudan. Journal of African Earth Sciences, 35, 331-344. https://doi.org/10.1016/S0899-5362(01)00097-5

[2] Rop, B.K. (2013) Petroleum Prospects under the Lotikipi Basin, North-Western 
Kenya. African Journal of Education, Science and Technology, 1, 7-18.

[3] Bosworth, W. and Morley, C.K. (1994) Structural and Stratigraphic Evolution of the Anza Rift, Kenya. Tectonophysics, 236, 93-115. https://doi.org/10.1016/0040-1951(94)90171-6

[4] Greene, L.C., Richards, D.R. and Johnson, R.A. (1991) Crustal Structure and Tectonic Evolution of the Anza Rift, Northern Kenya. Tectonophysics, 197, $203-211$. https://doi.org/10.1016/0040-1951(91)90041-P

[5] Alshakhs, M. and Rezaee, R. (2017) A New Method to Estimate Total Organic Carbon (TOC) Content, an Example from Goldwyer Shale Formation, the Canning Basin. Open Petroleum Engineering Journal, 10, 118-133. https://doi.org/10.2174/1874834101710010118

[6] Bakr, M. (2009) Occurrence and Geochemical Significance of Carbazoles and Xanthones in Crude Oil from the Western Desert, Egypt. Journal of King Abdulaziz University Earth Sciences, 20, 127-159. https://doi.org/10.4197/Ear.20-2.7

[7] Allan, A.A. (1990) Basin Analysis: Principles and Application to Petroleum Play Assessment. 3rd Edition, Blackwell Scientific Publications, Oxford.

[8] Hunt, J.M. (1996) Petroleum Geochemistry and Geology. 2nd Edition, WH Freeman, New York.

[9] Tissot, B., Durand, B., Espitalie, J. and Combaz, A. (1974) Influence of Nature and Diagenesis of Organic Matter in Formation of Petroleum. AAPG Bulletin, 58, 499-506. https://doi.org/10.1306/83D91425-16C7-11D7-8645000102C1865D

[10] Dindi (1994) Crustal Structure of the Anza Graben from Gravity and Magnetic Investigations. Tectonophysics, 236, 359-371. https://doi.org/10.1016/0040-1951(94)90184-8

[11] Lyaka, A.L. and Mulibo, G.D. (2018) Petrophysical Analysis of the Mpapai Well Logs in the East Pande Exploration Block, Southern Coast of Tanzania: Geological Implication on the Hydrocarbon Potential. Open Journal of Geology, 8, 781-802. https://doi.org/10.4236/ojg.2018.88046

[12] Kumar, S., Ojha, K., Bastia, R., Garg, K., Das, S. and Mohanty, D. (2017) Evaluation of Eocene Source Rock for Potential Shale Oil and Gas Generation in North Cambay Basin, India. Marine and Petroleum Geology, 88, 141-154.

https://doi.org/10.1016/j.marpetgeo.2017.08.015

[13] Bjorlykke, K. (2010) Petroleum Geoscience: From Sedimentary Environments to Rock Physics. Springer-Verlag, Berlin.

[14] Sen, S., Ghosh, I. and Kumar, M. (2015) Uncertainty in Well Log Analyses and Petrophysical Interpretations.

[15] Iheanacho, P.C. (2014) Formation-Resistivity Theory: How Archie Equations, Shaly-Reservoir Models, Conductive Rock-Matrix Model, and Dual-Triple-Porosity Models Are Related. SPE Nigeria Annual International Conference and Exhibition, Lagos, August 2013, Paper Number: SPE-167507-MS. https://doi.org/10.2118/167507-MS

[16] Rop, B. (1995) Geology and Hydrocarbon Potential of the Northwest Anza Basin Study. NOCK, Reconnaissance Report.

[17] Welte, D.H., Horsfield, B. and Baker, D.R. (2012) Petroleum and Basin Evolution: Insights from Petroleum Geochemistry, Geology and Basin Modeling. Springer Science \& Business Media, Berlin.

[18] Alaug, A.S. (2011) Source Rocks Evaluation, Hydrocarbon Generation and Palynofacies Study of Late Cretaceous Succession at 16/g-1 Offshore Well in Qamar Basin, 
Eastern Yemen. Arabian Journal of Geosciences, 4, 551-566. https://doi.org/10.1007/s12517-010-0182-6

[19] Curiale, J.A. (1993) Oil to Source Rock Correlation. In: Engel, M.H. and Macko, S.A., Eds. Organic Geochemistry: Principles and Applications, Springer US, Boston, 473-490. https://doi.org/10.1007/978-1-4615-2890-6_21

[20] Rop, B.K. (2003) Subsurface Stratigraphical Studies of Cretaceous-Tertiary Basins of Northwest Kenya. Unpubl. Ph Thesis, Pune University, Pune, 174 p.

[21] Espitalie, J., Deroo, G. and Marquis, F. (1985) Rock-Eval Pyrolysis and Its Application. Revue de I Institut Francais du Petrole, 40, 72.

https://doi.org/10.2516/ogst:1985035

[22] Peters, K.E. (1986) Guidelines for Evaluating Petroleum Source Rock Using Programmed Pyrolysis. AAPG Bulletin, 70, 318-329. https://doi.org/10.1306/94885688-1704-11D7-8645000102C1865D

[23] Deroo, G., Herbin, J.P., Roucaché, J., Tissot, B., Albrecht, P. and Schaeffle, J. (1978) Organic Geochemistry of Some Cretaceous Black Shales from Sites 367 and 368; Leg 41, Eastern North Atlantic. DSDP Initial Reports, 41, 865-874. https://doi.org/10.2973/dsdp.proc.41.129.1978

[24] McCarthy, K., Rojas, K., Niemann, M., Palmowski, D., Peters, K. and Stankiewicz, A. (2011) Basic Petroleum Geochemistry for Source Rock Evaluation. Oilfield Review, 23, 32-43.

[25] Peters, K.E. and Cassa, M.R. (1994) Applied Source Rock Geochemistry: Chapter 5: Part II. Essential Elements.

[26] Tissot, B., Califet-Debyser, Y., Deroo, G. and Oudin, J.L. (1971) Origin and Evolution of Hydrocarbons in Early Toarcian Shales, Paris Basin, France. AAPG Bulletin, 55, 2177-2193. https://doi.org/10.1306/819A3E2E-16C5-11D7-8645000102C1865D

[27] Chen, Z., Liu, X., Guo, Q., Jiang, C. and Mort, A. (2017) Inversion of Source Rock Hydrocarbon Generation Kinetics from Rock-Eval Data. Fuel, 194, 91-101.

https://doi.org/10.1016/j.fuel.2016.12.052

[28] Egbobawaye, E.I. (2017) Petroleum Source-Rock Evaluation and Hydrocarbon Potential in Montney Formation Unconventional Reservoir, Northeastern British Columbia, Canada. Natural Resources, 8, 716-756. https://doi.org/10.4236/nr.2017.811045

[29] Peters, K.E. and Simoneit, B.R.T. (1982) Rock-Eval Pyrolysis of Quaternary Sediments from Leg 64, Sites 479 and 480, Gulf of California. U.S. Government Printing Office, Washington DC. https://doi.org/10.2973/dsdp.proc.64.138.1982

[30] Akrout, D., Affouri, H., Ahmadi, R., Mercier, E. and Montacer, M. (2011) Source Rock Characterization and Petroleum Systems in North Ghadames Basin, Southern Tunisia. Resource Geology, 61, 270-280. https://doi.org/10.1111/j.1751-3928.2011.00163.x

[31] El Diasty, W.Sh., El Beialy, S.Y., Littke, R. and Farag, F.A. (2016) Source Rock Evaluation and Nature of Hydrocarbons in the Khalda Concession, Shushan Basin, Egypt's Western Desert. International Journal of Coal Geology, 162, 45-60. https://doi.org/10.1016/j.coal.2016.05.015

[32] Affouri, H., Montacer, M. and Disnar, J.-R. (2013) Organic Geochemistry of the Cenomanian-Turonian Bahloul Formation Petroleum Source Rock, Central and Northern Tunisia. Resource Geology, 63, 262-287. https://doi.org/10.1016/j.coal.2016.05.015

[33] Brooks, J.D., Gould, K. and Smith, J.W. (1969) Isoprenoid Hydrocarbons in Coal and Petroleum. Nature, 222, 257. https://doi.org/10.1038/222257a0 
[34] Peters, K.E. and Moldowan, J.M. (2017) Biomarker: Assessment of Thermal Maturity. In: White, W.M., Ed., Encyclopedia of Geochemistry: A Comprehensive Reference Source on the Chemistry of the Earth, Springer International Publishing, Cham, $1-8$.

[35] Peters, K.E., Moldowan, J.M. and Sundararaman, P. (1990) Effects of Hydrous Pyrolysis on Biomarker Thermal Maturity Parameters: Monterey Phosphatic and Siliceous Members. Organic Geochemistry, 15, 249-265.

https://doi.org/10.1016/0146-6380(90)90003-I

[36] Peters, K.E. and Moldowan, J.M. (1991) Effects of Source, Thermal Maturity, and Biodegradation on the Distribution and Isomerization of Homohopanes in Petroleum. Organic Geochemistry, 17, 47-61.

https://doi.org/10.1016/0146-6380(91)90039-M

[37] Abu Al-Atta, M., Ibrahim Issa, G., Ahmed, M.A. and Mustafa Afife, M. (2014) Source Rock Evaluation and Organic Geochemistry of Belayim Marine Oil Field, Gulf of Suez, Egypt. Egyptian Journal of Petroleum, 23, 285-302. https://doi.org/10.1016/j.ejpe.2014.08.005

[38] Bjorøy, M., Hall, K., Hall, P.B., Leplat, P. and Løberg, R. (1991) Biomarker Analysis of Oils and Source Rocks Using a Thermal Extraction-GC-MS. Chemical Geology, 93, 1-11. https://doi.org/10.1016/0009-2541(91)90060-5

[39] Moldowan, J.M., Seifert, W.K. and Gallegos, E.J. (1985) Relationship between Petroleum Composition and Depositional Environment of Petroleum Source Rocks. AAPG Bulletin, 69, 1255-1268. https://doi.org/10.1306/AD462BC8-16F7-11D7-8645000102C1865D 